\title{
CONVENTIONAL AND DEVELOPMENTAL SPRAYING TECHNIQUES FOR CONTROLLING WHITEFLY ATTACKING TOMATO PLANTS IN GREENHOUSES.
}

AMMAR, A. E.

Plant protection Research institute, A R C, Giza, Egypt

(Manuscript received 8 March 2006)

\section{Abstract}

Field experiments were undertaken in EI - Ismaillia Governorate, Egypt to evaluate the performance of two ground spraying techniques in greenhouse against whitefly Bemisia tabaci (Genn) infesting tomato plants during $2004 \& 2005$ seasons. Tested spraying equipment were : semco sprayer with hand lance at $6 \mathrm{~L} / \mathrm{fad}$. and conventional sprayer at $300 \mathrm{~L} /$ fad. with the use of Prempet and jojoba (plant extract) insecticides. Data indicated that semco sprayer with hand lance at $6 \mathrm{~L} / \mathrm{fad}$. gave satisfactory coverage on tomato plants amounted 93.75 and $90.7 \%$ and minimum lost between plants accounted for $0.59-1.48 \%$ and very poor contamination on the applicator by $5.66-8.14$ of spray deposit. But in case of conventional sprayer at $300 \mathrm{~L} /$ fad., percentage of spray deposit ranged presented by 42.7 and $34.2 \%$ on tomato plants, lost on land between tomato plants was 17.95 and $15.6 \%$, and contamination of applicator reached 47.43 and $41.7 \%$. Data showed that semco sprayer with hand lance at $6 \mathrm{~L} /$ fad. gave excellent control against whitefly by using recommended and $3 / 4$ recommended of Prempet insecticide at $300 \mathrm{~L} / \mathrm{fad}$. which presented by 80.9 and $67.1 \%$, respectively, followed by jojoba (plant extract) at $500 \mathrm{~L} / 100$ litre water with the same sprayer at recommended and 3/4 recommended rates give 68 . land $50.3 \%$, respectively. Meanwhile, conventional sprayer gave percent reduction ranged between 59.4 and 56.6 by using Prempet insecticide and 50.1 and $37.4 \%$ with jojoba (plant extract) at recommended and $3 / 4$ recommended respectively.

\section{INTERDUCTION}

The pesticide action is affected by several interfering factors, e.g. the pesticide type and its characters, spray quality and the contact between deposited spots and the target pest, which play a great role in determining the biological efficacy of the treatment. Within certain limits, smallest droplet the better is the actual efficacy. Accordingly, the application methods of a pesticide has decisive influence on the pesticidal action against the target pest. Moreover, measures aiming to minimizing drift or dropping the sprayed droplets during application are highly required economically and environmentally. Whitefly is considered as serious insect pests infesting tomato plants, causing heavy losses to their productivity. This insect transmit viral diseases to tomato plants. The ability of whitefly to develop insecticide resistance rapidly and inefficiency of ground application of several insecticides prevented satisfactory whitefly control. Ammar (1997) and Megahed et al. (2004). 
The present investigation was directed to spot light on the relation between spray coverage and pesticide efficiency against whitefly infested tomato plants. Evaluation of the performance of two used ground spraying equipment could help our choice for proper spraying techniques to be used in tomato plantations, in order to obtain satisfactory control results.

\section{MATERIALS AND METHODS}

\section{Spraying equipment,-}

Two ground sprayers used for pesticides application. The experimental work was done on tomato cultivated in at greenhouse in El -Ferdan, El-Ismailia Governorate.

\subsection{Comparison sprayer (Semco -MR-8)}

Comparison sprayer (Semco -MR-8) with a 8 liters tank, simple pump, pressure control valve, and a hand lance $(1 \mathrm{~m})$ having two small - sized flat-fan brass nozzles $\mathrm{Nr} 650017$ with one meter distance in between. Table (1)

\subsection{Target spraying equipment (conventional sprayer),}

A light portable knapsack sprayer of ten liters tank capacity and one spray«gun was tested on tomato plants. The sprayer is furnished with a simple hand pump with no air chamber. Table (1)

Table 1. Technical data of the spraying techniques applied on tomato plants during 2004 - 2005 seasons in greenhouse.

\begin{tabular}{|l|l|l|}
\hline Item & Semco with hand lance & Conventional sprayer \\
\hline Nozzle serial (Nr) & 650017 & Local \\
\hline Tank capacity (L.) & 6 & 10 \\
\hline Rate of application (L/fad.) & 6 & 300 \\
\hline Mean working speed (km/h.) & 2.4 & 2.4 \\
\hline Flow rate (L/min.) & 0.11 & 2.16 \\
\hline Productivity (fad/h) & 1.14 & 0.35 \\
\hline Swath width (m.) & 2.0 & 0.75 \\
\hline
\end{tabular}

2. Measuring and calculation of spray deposit,-

The following parameters were defined to fulfill the technical needs of the required field tests :

$$
\mathrm{Q}=\left(T \cdot R_{W} \cdot V_{0} / 252\right)
$$

Where :-

$$
\begin{array}{ll}
\mathrm{Q}=\text { flow rate }(\mathrm{L} / \mathrm{min}), & \mathrm{T}=\text { spraying volume }(\mathrm{L} / \mathrm{fad} .) \\
\mathrm{R}_{\mathrm{w}}=\text { effective run width }(\mathrm{m}) \text { and } & \mathrm{V}_{0}=\text { working speed }(\mathrm{km} / \mathrm{h})
\end{array}
$$

Suggested by Gabir et al. (1982). 


\section{Area :-}

Three greenhouse (two treatment + control) 4 replicates/treatment, each treatment comprised one kerate .

\section{Average climatic conditions :-}

Weather conditions were measured according to the method described by Barry (1978). Temperature $\left(2 \mathrm{C}^{\circ}\right)$, Relative humidity $(65 \%)$ and Wind velocity zero $\mathrm{m} / \mathrm{sec}$.

\section{Insecticide used,-}

1- Premet E.C., is a mixture, contains $15 \%$ fenpropathrin plus $5 \%$ of the juvenile hormone mimic pyriproxyfen, at recommended rate $0.3 \mathrm{~L} / \mathrm{fad}$.

2- Jojoba. Al-Kanz 2000, plant extract of Simmondsia Chinensis (link) (Buxaceae) used at $500 \mathrm{ml} / 100$ liter water.

\section{Sampling line :-}

Tomato plantations, grown in greenhouse ( 4 kerates) condition were chosen for experimentation. Chemical application were started $60-64$ days after the sowing of tomato plants. The cards were positioned on the top, middle and bottom levels of each tomato plant. Water sensitive paper (Ciba-Geigy) with the wire holders were fixed in " L shape" on the top of the holder. The cards positioned on head, thorax/abdomen and legs of applicator. All cards were collected and transferred carefully to the laboratory for measurement and calculation of the deposited droplets.

7. Determination of spray deposit :-

Number and size of spray deposit on cards were measured with a special scaled monocular lens (struben $($ ) with a magnification of XI5. The spread factor of used sensitive paper was 2.2 (Ciba - Geigy 1990).

\section{Biological counting and calculation :-}

Target: whitefly Bemisia tabaci.

Date of counting since application : after one day (initial kill) and 3, 5, 7, 9, 11, 13 and 15 days after application (as a latent effect)

Each treatment includes for replicates distributed in randomized block design. Each block contains untreated plot as a check. Numbers of whitefly on tomato plants were determined, as immature individuals existed on the upper surface of 80 leaves per each plot in laboratory.

Statistical analysis as mentioned by Hendrson and Teltan (1955) was used to calculated the percentage of reduction in the population. 


\section{RESULTS AND DISCUSSION}

\section{Qualitative distribution of Prempet deposited on tomato plants, losses on} land and contamination on applicator targets.

The obtained results confirmed the positive relationship between spraying volume and droplet size. The main studied factors affecting the spraying quality were: rate of application, the physical and chemical specifications of chemical, its formulations, and position of deposited spray (Osman 1983).

Data presented in Tables (283) showed a comparison between deposition on different targets, produced by semco ( $6.0 \mathrm{~L} / \mathrm{fad}$.) and conventional sprayer ( $300 \mathrm{~L} / \mathrm{fad}$.) using the full and three quarter of recommended rates. Prempet insecticide induced reduction in the number of droplets $/ \mathrm{cm}^{2}$ when big droplets were formed and deposited using HV conventional sprayer. The range of droplets number and size deposited on tomato plants using semco with hand lance, were 115 - 93 and $133-127$ um, respectively with the full and $3 / 4$ recommended rates. The spray lost between treated tomato plants was increased clearly in case of conventional sprayer in comparison with low volume semco sprayer. The obtained results are agree with Matthews and Thornhill (1994).

\subsection{Losses on land,-}

Data in Table (3) showed that very poor lost of droplets number between tomato plants in greenhouse when use semco sprayer with hand lance by 0.59 and $1.48 \%$ but in case of conventional sprayer and increase of lost droplet number was proved showing percentage to 17.7 and $15.6 \%$ with recommended and $3 / 4$ recommended rates respectively. This results agreed with Ammar (2003).

\subsection{Contamination of applicator :-}

Data in Table (3) show that the pollution with LV semco sprayer was $5.66 \%$ and $7.12 \%$ by using the full and $3 / 4$ recommended rates respectively. In the case of conventional sprayer the corresponding data were $43.1 \%$ and $41.7 \%$. Therefore, it is recommended to use low volume spraying in greenhouse instead of $\mathrm{HV}$ application for protecting the applicators.

The importance of this treatment was found to be agreed with the optimum size recommended by Smith and Goodhue (1942). according to this trend. Accordingly, it seems that the optimum size capable to realize a good level of controlling sucking insects should be situated within the fine-sized category of 15-150 micrometers with numbers not less than 50 droplets per one square centimeter. Taking into consideration the homogenous coverage of target possible and the lowest losses of spray to avoid contamination problem. 
Table 2. Spray coverage on tomato plants, losses on land and contamination of applicator targets as produced by tow different sprayers and two rates of Prempet insecticide against whitefly in greenhouse in 2004 \& 2005 seasons.

\begin{tabular}{|c|c|c|c|c|c|c|c|c|c|c|c|c|c|c|}
\hline \multicolumn{3}{|c|}{ Equipment } & \multicolumn{6}{|c|}{ Semco sprayer with hand lance } & \multicolumn{6}{|c|}{ Conventional sprayer } \\
\hline \multicolumn{3}{|c|}{$\begin{array}{l}\text { Spraying volume } \\
\text { (L/fad.) }\end{array}$} & \multicolumn{6}{|c|}{6.0} & \multicolumn{6}{|c|}{300.0} \\
\hline \multicolumn{3}{|c|}{ Dose rate } & \multicolumn{3}{|c|}{ Recom. } & \multicolumn{3}{|c|}{ 3/4 Recom. } & \multicolumn{3}{|c|}{ Recom. } & \multicolumn{3}{|c|}{ 3/4 Recom. } \\
\hline \multicolumn{3}{|c|}{ Target \& position } & VMD & $\mathrm{N} / \mathrm{cm}^{2}$ & $\mathrm{~N} \%$ & VMD & $\mathrm{N} / \mathrm{cm}$ & $\mathrm{N} \%$ & VMD & $\mathrm{N} / \mathrm{cm}^{2}$ & $\mathrm{~N} \%$ & VMD & $\mathrm{N} / \mathrm{cm}^{2}$ & N\% \\
\hline \multirow{4}{*}{ 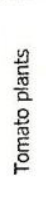 } & \multicolumn{2}{|l|}{ Upper } & 131 & 115 & 36.5 & 133 & 113 & 36.6 & 670 & 15 & 48.4 & 655 & 18 & 43.9 \\
\hline & \multicolumn{2}{|l|}{ Middle } & 130 & 105 & 33.3 & 131 & 103 & 33.3 & 630 & 10 & 32.3 & 627 & 14 & 34.1 \\
\hline & \multicolumn{2}{|l|}{ Lower } & 127 & 95 & 30.2 & 128 & 93 & 30.1 & 620 & 6 & 19.3 & 615 & 9 & 22.0 \\
\hline & \multicolumn{2}{|l|}{ Average } & 129.3 & 105 & & 130.7 & 103 & & 640 & 10.3 & & 632.3 & 13.7 & \\
\hline \multicolumn{3}{|c|}{ Losses on land } & 120 & 2 & & 118 & 5 & & 645 & 14 & & 640 & 15 & \\
\hline \multirow{7}{*}{ 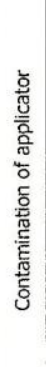 } & Head & & 0 & 0 & & 0 & 0 & & 0 & 0 & & 0 & & \\
\hline & \multirow{2}{*}{$\begin{array}{l}\text { Thorax / } \\
\text { Abdomen }\end{array}$} & $R$ & 141 & 3 & 42.9 & 135 & 6 & 54.5 & 630 & 7 & 53.8 & 625 & 8 & 53.3 \\
\hline & & L & 130 & 4 & 57.1 & 137 & 5 & 45.5 & 633 & 6 & 46.2 & 620 & 7 & 46.7 \\
\hline & Average & & 135.5 & 3.5 & & 136 & 5.5 & & 631.5 & 6.5 & & 622.5 & 7.5 & \\
\hline & \multirow[t]{2}{*}{ Legs } & $R$ & 114 & 5 & 41.7 & 100 & 7 & 53.8 & 615 & 10 & 47.6 & 605 & 12 & 48 \\
\hline & & L & 110 & 7 & 58.3 & 105 & 6 & 46.2 & 610 & 11 & 52.4 & 600 & 13 & 52 \\
\hline & Average & & 112 & 6 & & 102.5 & 6.5 & & 612.5 & 10.5 & & 602.5 & 12.5 & \\
\hline
\end{tabular}

$R=$ Right $\quad L=$ Left

VMD = volume mean diameter

$\mathrm{N} / \mathrm{cm}^{2}=$ number of droplet $/ \mathrm{cm}^{2}$

Table 3. Percentage of deposit spray on tomato plants, losses on land and contamination of applicator by two different ground sprayer.

\begin{tabular}{|l|l|l|l|l|}
\hline \multicolumn{1}{|c|}{ Equipment } & \multicolumn{2}{c|}{ Semco with hand lance } & \multicolumn{2}{c|}{ Conventional sprayer } \\
\hline Dose rate & Recom. & $3 / 4$ recom. & Recom. & $3 / 4$ recom. \\
\hline Tomato plants \% & 93.75 & 91.4 & 39.2 & 42.7 \\
\hline Losses on land \% & 0.59 & 1.48 & 17.7 & 15.6 \\
\hline Contamination of applicator \% & 5.66 & 7.12 & 43.1 & 41.7 \\
\hline
\end{tabular}

1.3. Bioefficiency of spraying techniques:-

Data presented in Table (4) showed the initial and residual effects of Prempet, with semco and a conventional sprayer. Excellent control of whitefly was found when applying semco sprayer at the full and three quarter of recommended rates. The 
percentages of reduction of whitefly infesting tomato was ranged between 80.9 - 67.1 $\%$ up to 15 days after application. Poor reduction was recorded by using the conventional sprayer with the same rates. These results are agree with Ammar (2003).

Data in Table (4) showed that jojoba oil applied with the conventional sprayer revealed poor control of whitefly on tomato plants in greenhouse. The mean percentage reduction of infestation was 50.1 and $37.4 \%$ applying the full and $3 / 4$ recommended rates, respectively. Using semco sprayer with hand lance exerted excellent control results against whitefly. The average percentage reduction of infestation was 68.1 and $50.3 \%$. These results agreed with Walkers (1971) who gave a great consideration to the infiuence of droplet size of the boiefficiency of spray particularly in space of application used for directing airborne droplets to flying insects, Megahed et al. (2004).

Table 4. Percentage reduction of whitefly infestation on tomato plants, 15 days after application with tested insecticides and two application techniques during $2004 \& 2005$ seasons in greenhouse.

\begin{tabular}{|c|c|c|c|c|c|c|}
\hline \multicolumn{3}{|c|}{ Equipment } & \multicolumn{2}{|c|}{ Semco sprayer with hand lance } & \multicolumn{2}{|c|}{ Conventional sprayer } \\
\hline \multicolumn{3}{|c|}{ Spraying volume (L/fad.) } & \multicolumn{2}{|c|}{6.0} & \multicolumn{2}{|c|}{300.0} \\
\hline \multicolumn{3}{|c|}{ Rates } & Recom. & $3 / 4$ recom. & Recom. & $3 / 4$ recom. \\
\hline \multirow{6}{*}{ 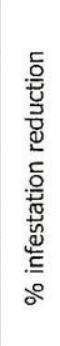 } & \multirow{3}{*}{$\begin{array}{l}\overline{0} \\
\tilde{0} \\
\overline{0} \\
\text { ஜू } \\
0\end{array}$} & Initial & 54.2 & 37.8 & 36.9 & 20.3 \\
\hline & & Residual & 82.0 & 62.8 & 63.2 & 54.4 \\
\hline & & Average & 68.1 & 50.3 & 50.1 & 37.4 \\
\hline & \multirow{3}{*}{ 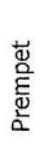 } & Initial & 65.7 & 53.9 & 43.6 & 45.9 \\
\hline & & Residual & 96.2 & 80.2 & 75.2 & 67.3 \\
\hline & & Average & 80.9 & 67.1 & 59.4 & 56.6 \\
\hline
\end{tabular}

2. Qualitative distribution of jojoba oil deposits on tomato plants, losses on land, and contamination of applicators.

Data presented in Table (5) showed a comparison between deposition on different target, produced by semco at $6.0 \mathrm{~L} / \mathrm{fad}$. and conventional sprayer at 300 (L/fad.) using the full and three quarter recommended rates. Jojoba oil induced reduction in the number of droplet $/ \mathrm{cm}^{2}$ when big droplets were formed using $\mathrm{HV}$ conventional sprayer. The mean of droplets number and size of spray deposit on tomato plants using semco with hand lance was 101.3 and 104 and 136.3 and $133.3 \mathrm{p}$, with the full and $3 / 4$ recommended rates, respectively. 
Table 5. Spray coverage on tomato plants, losses on land and contamination of applicator targets as produced by two different sprayers and two rates of jojoba, insecticide against whitefly in greenhouse in 2004 \& 2005 seasons.

\begin{tabular}{|c|c|c|c|c|c|c|c|c|c|c|c|c|c|c|}
\hline \multicolumn{3}{|c|}{ Equipment } & \multicolumn{6}{|c|}{ Semco sprayer with hand lance } & \multicolumn{6}{|c|}{ Conventional sprayer } \\
\hline \multicolumn{3}{|c|}{$\begin{array}{l}\text { Spraying volume } \\
\text { (L/fad.). }\end{array}$} & \multicolumn{6}{|c|}{6.0} & \multicolumn{6}{|c|}{300.0} \\
\hline \multicolumn{3}{|c|}{ Dose rate } & \multicolumn{3}{|c|}{ Recom. } & \multicolumn{3}{|c|}{$3 / 4$ recom. } & \multicolumn{3}{|c|}{ Recom. } & \multicolumn{3}{|c|}{$3 / 4$ recom. } \\
\hline \multicolumn{3}{|c|}{ Target \& position } & VMD & $\mathrm{N} / \mathrm{cm}^{2}$ & $N \%$ & VMD & $\mathrm{N} / \mathrm{cm}^{2}$ & N\% & VMD & $\mathrm{N} / \mathrm{cm}^{2}$ & $\mathrm{~N} \%$ & VMD & $\mathrm{N} / \mathrm{cm}^{2}$ & N\% \\
\hline \multirow{4}{*}{ 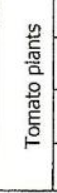 } & \multicolumn{2}{|l|}{ Upper } & 140 & 109 & 35.9 & 138 & 110 & 35.3 & 675 & 13 & 48.1 & 670 & 15 & 48.4 \\
\hline & \multicolumn{2}{|l|}{ Middle } & 137 & 100 & 32.9 & 135 & 105 & 33.7 & 660 & 9 & 33.3 & 655 & 10 & 32.3 \\
\hline & \multicolumn{2}{|l|}{ Lower } & 132 & 95 & 31.2 & 127 & 97 & 31.0 & 655 & 5 & 18.6 & 650 & 6 & 19.3 \\
\hline & \multicolumn{2}{|l|}{ Average } & 136.3 & 101.3 & & 133.3 & 104 & & 663.3 & 9 & & 658.3 & 10.3 & \\
\hline \multicolumn{3}{|c|}{ Losses on land } & 130 & 3 & & 127 & 4 & & 650 & 14 & & 650 & 13 & \\
\hline \multirow{7}{*}{ 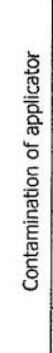 } & \multicolumn{2}{|l|}{ Head } & 0 & 0 & & 0 & 0 & & 0 & 0 & & 0 & 0 & \\
\hline & \multirow{2}{*}{$\begin{array}{l}\text { Thorax / } \\
\text { Abdomen }\end{array}$} & $R$ & 121 & 5 & 45.5 & 115 & 4 & 44.4 & 640 & 6 & 54.5 & 640 & 7 & 53.8 \\
\hline & & L & 120 & 6 & 54.5 & 100 & 5 & 55.6 & 642 & 5 & 45.5 & 640 & 6 & 46.2 \\
\hline & \multicolumn{2}{|l|}{ Average } & 120.5 & 5.5 & & 107.5 & 4.5 & & 641 & 5.5 & & 640 & 6.5 & \\
\hline & \multirow[t]{2}{*}{ Legs } & $R$ & 125 & 5 & 41.7 & 105 & 9 & 47.4 & 630 & 12 & 46.2 & 633 & 11 & 47.8 \\
\hline & & $\mathrm{L}$ & 118 & 7 & 58.3 & 98. & 10 & 52.6 & 625 & 14 & 53.8 & 627 & 12 & 52.2 \\
\hline & \multicolumn{2}{|l|}{ Average } & & 6 & & 101.5 & 9.5 & & 627.5 & 13 & & 630 & 11.5 & \\
\hline
\end{tabular}

$\mathrm{R}=$ Right $\quad \mathrm{L}=\mathrm{Left} \quad \mathrm{VMD}=$ volume mean diameter

$\mathrm{N} / \mathrm{cm}^{2}=$ number of droplet $/ \mathrm{cm}^{2}$

2.1 Losses on land :-

Data in Table (6) showed that the spray lost between treated tomato plants was increased clearly in case of conventional sprayer amounted 17.95 and 16.25 comparison with low volume semco sprayer accounted for 0.19 and 1.16 at full and $3 / 4$ recommended rates respectively, the results agreed with Matthews and Thornhill (1994).

2.2. Contamination of applicator :-

Data in Table (6) showed high contamination of applicator due to the use of conventional sprayer by 47.43 and $45.00 \%$ compared with semco with hand lance by 6.99 and $8.14 \%$ at full and $3 / 4$ recommended rates, respectively. 
Table 6. Percentage of deposit spray on tomato plants, losses on land and contamination of applicator as produced by two different ground sprayer.

\begin{tabular}{|l|l|l|l|l|}
\hline Equipment & \multicolumn{2}{l|}{ Semco with hand lance } & \multicolumn{2}{l|}{ Conventional sprayer } \\
\hline Do^e rate & Recom. & $3 / 4$ Recom. & Recom. & 3/4 Recom. \\
\hline Tomato plants \% & 92.1 & 90.7 & 34.62 & 38.75 \\
\hline Losses on land \% & 0.91 & 1.16 & 17.95 & 16.25 \\
\hline Contamination of applicator \% & 6.99 & 8.14 & 47.43 & 45.00 \\
\hline
\end{tabular}

\section{REFERENCES}

1. Ammar, A. E. 1997. Studies on certain aerial and ground techniques for controlling the common sucking insects of cotton. M. Sc. Thesis, Zagazig Univ. 86pp.

2. Ammar, A. E. 2003. Studies on certain techniques for pesticide applications. Ph. D. Thesis, Fac. of Agric., Zagazig Univ. 169 pp.

3. Barry, J. W. 1978. Meteorological conditions and measurements. Tech. Bull. U. S. A. 1596:34-37.

4. Ciba Geigy 1990. International training course for the safe and efficient handling and applications of plant protection agents Ciba - Giegy Ltd., Agric. Div. Applic. Advisory Serv. Vol. 1, pp 1-6.

5. Gabir, I., Z. H. Zidan, E. Attalah, and M. A. Hindy. 1982. Calibration ${ }^{5}$ and evaluation of the performance of certain hydraulic nozzle types under 4aboratory conditions. Res. Bull. 1738 Fac. Agric., Univ. Ain Shams, Egypt.

6. Henderson, C. F. and E. W. Telton. 1955. Tests with acaricides against the brown wheat mite. J. Econ. Entom., 48 (1): 157-161.

7. Mathews, G. A. and E. W. Thornhill. 1994. Hydraulic nozzles pesticide application equipment for use in agriculture. "Manually carried equipment". Agric. Serv. Bull. (FAO) $1: 20-24$.

8. Megahed, H. E., M. M. A. Ibraheem, A. A. A. Abd-Allah and H. M. H. Al-Shannef. 2004. Effects of certain Bio-products in comparison with some insecticides against Thrips tabaci (Lind) infesting onion and garlic plants Zagazig J. Agric. Res. Vol-31 No. (5) 2393 - 2404.

9. Osman, G. 1983. Determination and calculation of droplets in the control of agricultural pests. M. Sc. Thesis, Fac. Agric. Ain-Shams, Univ. 194 PP.

10. Smith, F. F. and L. D. Goodhue. 1942. DDT aerosol to control onion thrips and other pests in greenhouse. J. Econ. Ent. 38 (2): $173-179$.

11. Walker, D. A. 1971. Notes on ultra-low volume aerial application equipment and techniques. EPPO. Bull. 2: 115 - 121. 


$$
\begin{aligned}
& \text { مقارنة الرش التقلّيدى والمطور لمكافحة الأبابة البيضاء على } \\
& \text { الطماطم داخل الصوب الزراعية } \\
& \text { عبدالمجيد السيد عمار } \\
& \text { معهد بحوث وقابية النباتات -مركز البحوث الزراعية - الجبزة - مصر }
\end{aligned}
$$

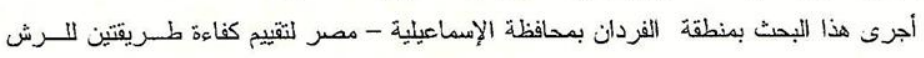

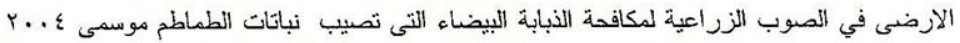

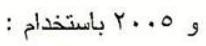

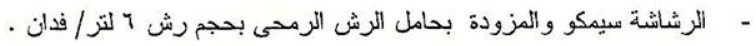

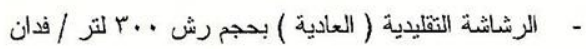

$$
\begin{aligned}
& \text { استخدمت المبيدات التالية فى الارراسة :- }
\end{aligned}
$$

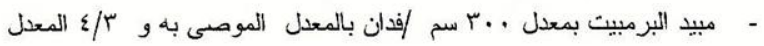

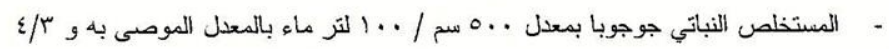

$$
\begin{aligned}
& \text { المعدل . } \\
& \text { وقد أوضحت النتائج :- المعال }
\end{aligned}
$$

- عند الستخدام الرشاشة سيمكو المزودة بحامل الرش الرمحى بحجم رش 1 لتزر / فدان اعطت تغطية

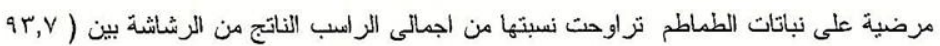

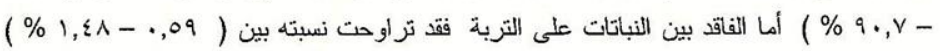

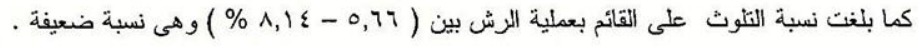

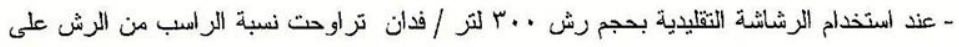

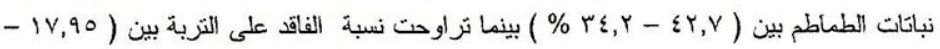

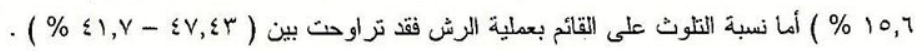

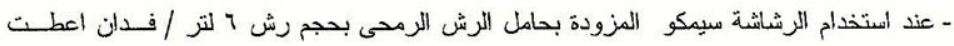

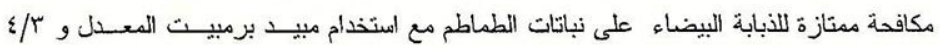

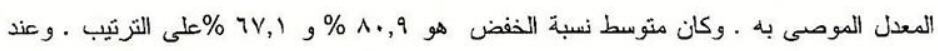

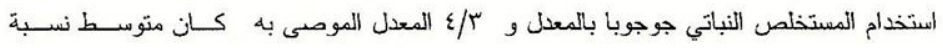

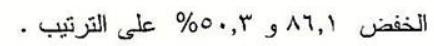

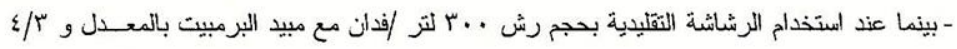

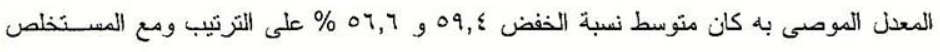

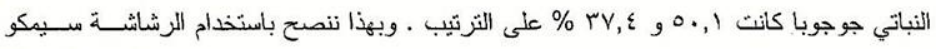

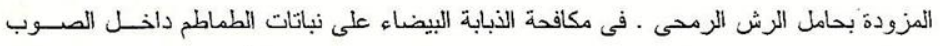

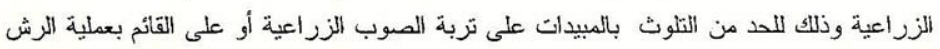

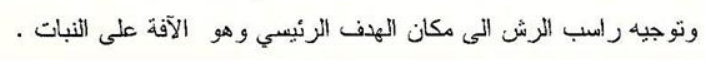

